\title{
Impact of pharmaceutical industry treated effluents on the water quality of river Uppanar, South east coast of India: A case study
}

\author{
Usha Damodhar • M. Vikram Reddy
}

Received: 9 October 2012/ Accepted: 25 March 2013/Published online: 26 April 2013

(C) The Author(s) 2013. This article is published with open access at Springerlink.com

\begin{abstract}
The water quality of a river that received pharmaceutical industrial effluents is evaluated through the analysis of two indices to describe the level of pollution of the river, in this paper. The indices have been computed from December 2009 to June 2011 at four sampling stations-outlet, outfall, upstream, and downstream in the Uppanar River located at Cuddalore (South east coast of India). The results were compared with the guidelines of Bureau of Indian standards for drinking water specifications (BIS 10500). The study also identifies the pollutants of pharmaceutical industrial effluents before and after treatment that affects the river water quality. Data on spatial and temporal changes in dissolved oxygen, biochemical oxygen demand, chemical oxygen demand, $\mathrm{pH}$, temperature, color, electrical conductance, total dissolved solids, total suspended solids, calcium, magnesium, hardness, sodium, and chloride were collected. The water quality indices used, Bascarón (1979) adapted Water Quality Index $\left(\mathrm{WQI}_{\mathrm{BA}}\right)$ and the Canadian Council of Ministers of the Environment-Water Quality Index 1.0 (CCME WQI), which is a well-accepted and universally applicable computer model for evaluating the water quality index. Both the indices presented similar trends, and were considered adequate for evaluating the impacts of industrial effluent on the river water bodies.
\end{abstract}

Keywords Water quality indices $\cdot$ River $\cdot$ Pharmaceutical industrial effluents $\cdot$ Anthropogenic impact

\footnotetext{
U. Damodhar · M. Vikram Reddy $(\bowtie)$

Department of Ecology and Environmental Sciences,

Pondicherry University, Pondicherry 605014, India

e-mail: prof.mvikramreddy@yahoo.com

U. Damodhar

e-mail: ushadamodhar@gmail.com
}

\section{Introduction}

Anthropogenic pollution of river waters caused by factors, such as industry, agriculture and human sewage, is an issue of great concern, since together with population growth and climate change, and it can have large scale adverse impacts on the surface water quality. In recent years, it has become clear that pharmaceuticals released into environment are an important group of environmental pollutants (Jorgensen and Halling-Sorensen 2000). Many reports have been published that proves the widespread occurrence of these pollutants in waste water, surface water and ground water (Heberer 2002; Hernando et al. 2004; Stackelberg et al. 2004; Cahill et al. 2004; Debska et al. 2004; Gomez et al. 2006). Pharmaceuticals that are made to interact with living organisms can also have acute effects on fauna and flora, but due to low concentrations this will not be the biggest concern (Jones et al. 2004). In this article, an attempt is made using two water quality indices to quantify the pollutants in the waste water and surface water samples.

The use of water quality indices (WQI) simplifies the presentation of results of any analysis related to a water body, as it summarizes in one value or concept a series of analyzed parameters. WQI are generally considered as measuring means of shortening various water quality parameters into a simple index (Horton 1965; Brown et al. 1970; Dinius 1972; Lohani and Todino 1984). Nevertheless, the indices are very useful to pass on the information about water quality to the public in general, giving a fine idea of the progressive trend of water quality changing over a period of time, besides allowing the comparison between different watercourses or different locations along the same course. Indices are important tools for administration of hydrographic basins (Almeida and Schwarzbold 2003). 
The index choice depends on the pollution sources present at the location and the proposed use of the water, and also on the options of accomplishing analysis for the necessary parameters. A highly flexible index denominated $\mathrm{WQI}_{\mathrm{BA}}$ allows the foundation or elimination of parameters in agreement with the needs or restrictions for data acquisition (Bascarón 1979). In Canada, a new water quality index was introduced in the mid-1990s by the province of British Columbia and used it as the basis for reporting to the public regarding water quality control and management measures (Rocchini and Swain 1995; SOE Report 1997, Zandbergen and Hall 1998). The WQI has the ability to convey relative differences in water quality between sites (Canadian Council of Ministers of the Environment (CCME) 2001). However, the interdependency of these parameters makes the evaluation process inaccurate. Therefore, it is essential to study the correlation among the parameters considered (Raphael Abrahão 2007).

The Uppanar River was chosen for the present study because it represents an environmental degradation situation, which is becoming more and more frequent in developing countries. Employment opportunities and economic growth of a region being the main objectives, industrial areas are created and their activities are developed without the proper consideration of their environmental impacts. In this way, rivers and streams receive great volumes of industrial effluents daily, which frequently are incompatible with their flow and auto in-stream recovery capacity.

The main aim of the study was to evaluate the impacts of pharmaceutical industrial effluents on river water quality. The study highlights the vital parameters affecting the river water quality at the various locations at SIPCOT (Southern Industries and Petro Chemical Corporation of Tamil Nadu) Cuddalore, India. The study is divided into three phases: (1) application of $\mathrm{WQI}_{\mathrm{BA}}$ and CCME WQI to the river stretch between upstream and downstream to evaluate water quality index of selected parameters; (2) establishing the correlation between the water quality index and the different parameters; and (3) to identify the most critical parameters affecting the water quality of the river.

\section{Water quality index}

The significance of the WQI can be appreciated as the water resources play a crucial role in the overall environment and this index has also been recognized as one of the 25 environmental performance indicators of the holistic Environmental Performance Index (EPI). The EPI is based on the well-established policy categories covering both environmental public health and ecosystem vitality, which focus on climate change, water quality and quantity, biodiversity, land-use changes, deforestation and sustainability of agriculture and fisheries (EPI 2010).

The major statistical look to WQI indices was given by Landwehr (1974), whose doctoral work culminated in the classification of the water based on the numerical values of indices as follows: very bad: 0-20; bad: $21-45$; medium: 46-75; good: 76-90; very good/excellent: 91-100. He also concluded that a multiplicative water quality index was a more viable and unbiased estimator of water quality that best reflected the consensus of the experts (Landwehr and Deininger 1976; Landwehr 1979). Water quality of many Indian rivers has been comprehensively studied, analyzed and reported according to their suitability for various beneficial uses (Bhargava 1983, 1994).

\section{Description of the study area}

The Uppanar River is located in the state of Tamil Nadu, South east coast of India, and its length is approximately $5.2 \mathrm{~km}$. Its basin is located at (Lat. $11 / 43^{\prime} \mathrm{N}$, Long. $79 / 46^{\prime} \mathrm{E}$ ) an average elevation of about $1 \mathrm{~m}$ above sea level (Fig. 1). The average annual rainfall of the Cuddalore district is $1,902 \mathrm{~mm}$. The river receives rainwater from southwest monsoon (June-September), northeast monsoon (OctoberDecember) and non-monsoon periods (January-May). The rainfall is generally heavy during low-pressure depressions and cyclones during the northeast monsoon period. The normal annual rainfall is $1,119.8 \mathrm{~mm}$. The area falls under tropical climate with higher temperature in the summer months of March to May. The lower section of the river's catchment area is predominantly influenced by agriculture, while the upper water course is affected by domestic sewage as well as by wastewater discharge from industries.

A great portion of the Uppanar river basin is occupied by the industrial zone of SIPCOT, with an area of 646 ha and it comprises 155 companies, but only 83 are currently in operation. These industries are of several types-metallurgical and pharmaceuticals, paints and fertilizers and pesticides industries. Because the beginning of the industrial activities in 2004, the Uppanar River has become the primary receiver and diluter of the liquid effluents discharged, as the industrial district area is cut off by the stream. Of the 83 active companies, 59 discharge their liquid effluents into the stream, either directly or indirectly (through a collecting system). The majority of the industries located in the Industrial zone of SIPCOT do not have adequate and efficient treatment of the generated effluents. The problem with effluent treatment occurs more frequently with small industries that do not use treatment to decrease discharge in the final form, and due to the lack of adequate inspections, dispose of the effluents into the watercourses of the area. 


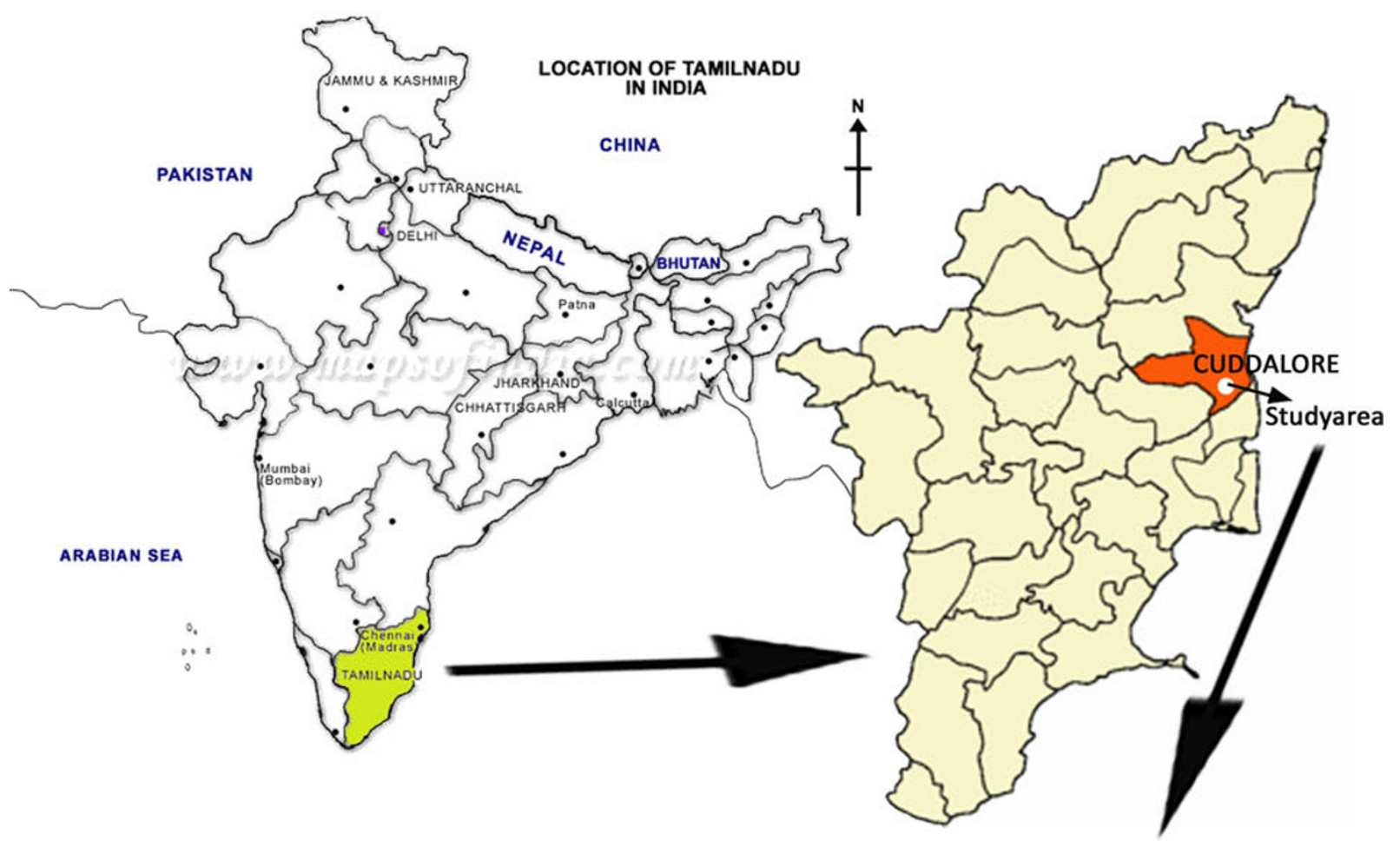

$79^{\circ} 30^{\prime} \mathrm{E}$

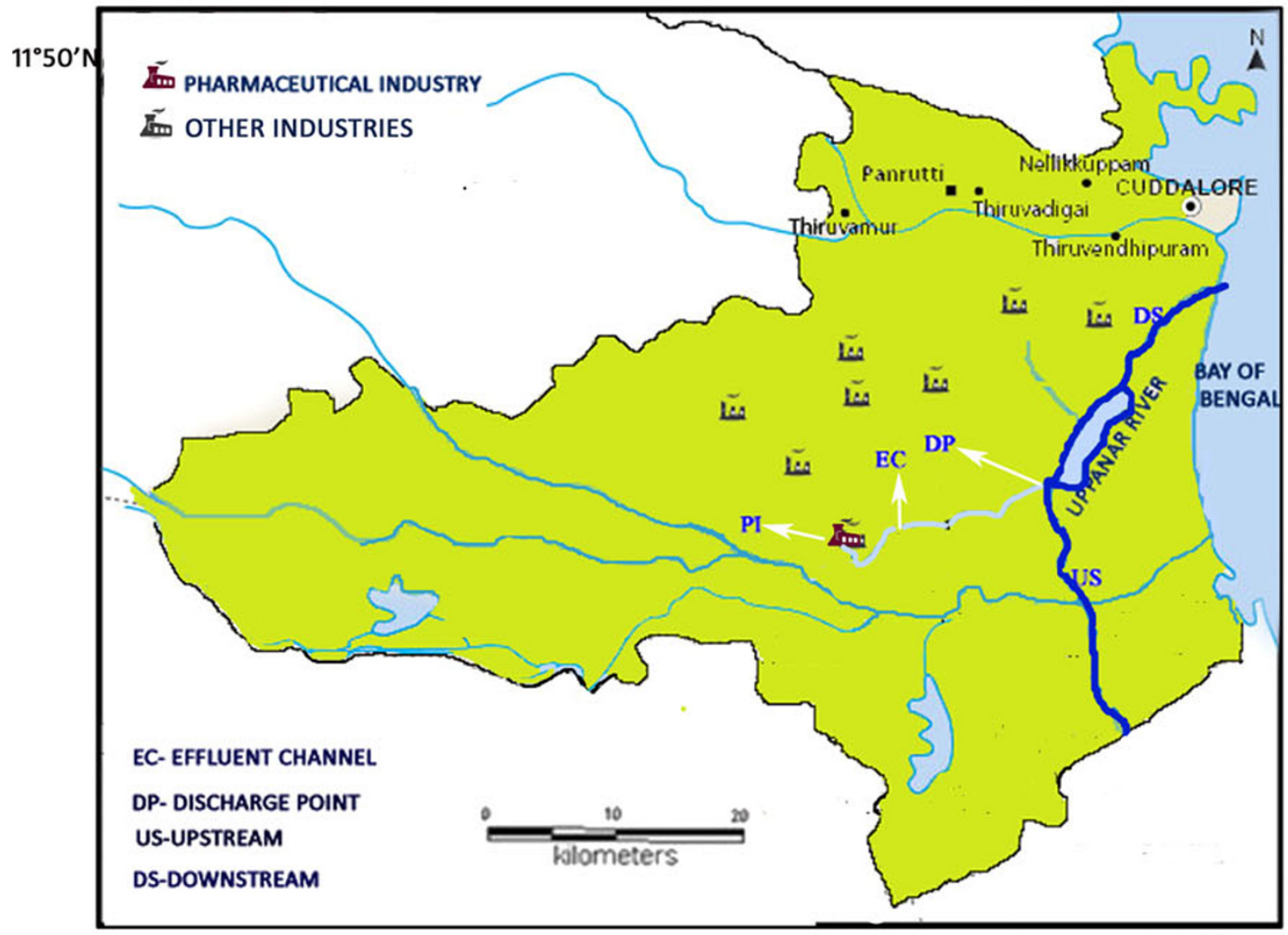

$11^{\circ} 40^{\prime} \mathrm{N}$

$79^{\circ} 45^{\prime} \mathrm{E}$

Fig. 1 Uppanar River at Cuddalore 


\section{Materials and methods}

Wastewater and river water sampling

In this study, six different sampling sites-the influent (untreated waste water), effluent (treated waste water), and effluent discharge point (outlet) of the wastewater treatment plant (WWTP) in the river basin and at three different points, upstream and downstream from the WWTP and its emission point were monitored and the contaminants were assessed. The influent and effluent wastewater samples were taken from the WWTP of the pharmaceutical industry of the SIPCOT (Southern Industries Petro Chemical Corporation of Tamil Nadu) industrial complex located adjacent to the Cuddalore old town. This plant applies a pretreatment for solid removal, a primary treatment to eliminate suspended material, an activated sludge biological treatment and final clarification. This WWTP discharges directly into the Uppanar River. The water samples analyzed in this study were collected from different points along the river (Fig. 1), covering an area of about $1,000 \mathrm{~km}^{2}$. The width of the river in most of the sampling points is about $10 \mathrm{~m}$. The samples were taken at the middle of width of the river. Sampling was carried out $20 \mathrm{~m}$ (WWTP-outlet), $540 \mathrm{~m}$ (outfall) and $1,150 \mathrm{~m}$ (downstream, contaminated) from the pharmaceutical WWTP discharge point and 25,000 $\mathrm{m}$ (upstream, uncontaminated) of the WWTP. Effluents and public sewage are well mixed with the river water at the sampling points downstream the WWTP. A total number of 342 (228 water samples from river and 114 wastewater samples from WWTP) were collected at six different sampling sites and analyzed. The samplings were done across six different seasons viz. winter 2010 (December 2009-February 2010), summer 2010 (March 2010-May 2010), southwest monsoon 2010 (June 2010-September 2010), northeast monsoon 2010 (October 2010-November 2010), winter 2011(December 2010-February 2011) and summer 2011 (March 2011-June 2011). In each season, waste water from WWTP and river water sampling was carried out in triplicates every month, and samples were collected using high-density polythene containers at four sampling sites. During the studied period, the flow of the river has not changed significantly. The mean flow rate ranged from 5.66 to 7.68 at river points upstream of the WWTP and between 12.13 and 13.94 at the points downstream from the WWTP discharge point (Central Pollution Control Board (CPCB) 2006). Data referring to 19 months of monitoring were utilized to evaluate, through the use of the $\left(\mathrm{WQI}_{\mathrm{BA}}\right)$ and $(\mathrm{CCME}$ WQI), the impacts of industrial effluents on the water quality of Uppanar River. Water samples were collected using the APHA methods. The $\mathrm{pH}$, temperature, electrical conductivity, TDS of the samples was determined using a multi-parameter tester. The TSS, turbidity, calcium ion, magnesium ion, total hardness, sodium, chloride, dissolved oxygen, $\mathrm{COD}$ and $\mathrm{BOD}_{5}$ were determined using standard methods. All procedures for the analyses carried out are in agreement with the methodology described in Standard Methods (1995).

Water quality indices

Calculation of $W Q I_{B A}$

The parameters used for the calculation of the $\mathrm{WQI}_{\mathrm{BA}}$ indices were color, $\mathrm{pH}, \mathrm{BOD}_{5}$, $\mathrm{DO}$, temperature, hardness, TDS, sodium, chloride, EC, magnesium, and calcium.

Bascarón Water Quality Index $\left(\mathrm{WQI}_{\mathrm{BA}}\right)$, equation (Bascarón 1979):

$\mathrm{WQI}_{\mathrm{BA}}=K \frac{\sum C_{i} P_{i}}{\sum p_{i}}$

where $C_{i}$ percentage value corresponding to the parameter, $P_{i}$ parameter weight, defined in Table $1 K$ constant of adjustment in function of the visual aspect of the water, as follows: 1.00 for clear water with no apparent contamination; 0.75 for water with slightly unnatural color (colour red or colour blue) and with foam; 0.50 for polluted appearance water with odour between moderate and strong; 0.25 for dark water that presents fermentation and strong odor (Bascarón 1979).

\section{Calculation of CCME WQI}

In the formulation of water quality index, the importance of various parameters depends on the intended use of water and water quality parameters are studied from the point of view of suitability for human consumption. The BIS for drinking water specifications (IS 10500) have been quoted.

Conceptually, CCME WQI comprises three factors and is well documented (CCME 2001).

Factor $1\left(F_{1}\right)$ deals with scope that assesses the extent of water quality guidelines noncompliance over the time period of interest.

$F_{1}=\left[\frac{\text { Number of Failed parameters }}{\text { Total Number of Failed parameters }}\right] \times 100$

Factor $2\left(F_{2}\right)$ deals with frequency, i.e. how many occasions the tested or observed value was off the acceptable limits or the yardsticks.

$F_{2}=\left[\frac{\text { Number of Failed tests }}{\text { Total Number of Failed test }}\right] \times 100$

Factor $3\left(F_{3}\right)$ deals with the amplitude of deviation or the amount by which the objectives are not met. F3 represents amplitude: The extent (excursion) to which the 
Table 1 Comparison of average value of parameters with IS: 10,500

\begin{tabular}{lccccccc}
\hline Parameters & Winter 2010 & Summer 2010 & SW 2010 & NE 2010 & Winter 2011 & Summer 2011 & Permissible Limit \\
\hline pH & 8 & 8 & 7 & 7 & 8 & 7 & $6.5-8.5$ \\
Temperature & 27.500 & 28.250 & 27.250 & 27.500 & 26.250 & 28.875 & Nil \\
EC & 694.08 & 891.67 & 1733.13 & 811.25 & 723.13 & 913.75 & Nil \\
TDS & 362.42 & 464.63 & 873.81 & 480.63 & 354.38 & 495.00 & $500-2,000$ \\
TSS & 50.167 & 50.000 & 50.991 & 348.750 & 65.500 & 305.688 & Nil \\
DO & 5.450 & 4.808 & 5.738 & 4.734 & 5.781 & 3.695 & $30-100$ \\
BOD & 34.50 & 39.42 & 39.94 & 43.19 & 52.13 & 42.50 & Nil \\
COD & 194.75 & 218.42 & 215.44 & 139.50 & 200.19 & 131.31 & Nil \\
Calcium & 42.37 & 39.82 & 38.15 & 55.86 & 48.09 & 36.75 & $75-200$ \\
Magnesium & 18.19 & 17.85 & 16.43 & 23.52 & 22.51 & 17.36 & $30-100$ \\
Hardness & 180.75 & 172.75 & 163.05 & 236.1 & 212.75 & 162.975 & $300-600$ \\
Sodium & 84.59 & 97.61 & 70.69 & 73.24 & 100.12 & 99.64 & Nil \\
Chloride & 139.16 & 166.18 & 137.45 & 131.20 & 176.97 & 168.44 & $250-1,000$ \\
\hline
\end{tabular}

failed test exceeds the guideline. This is calculated in three stages. First, the excursion is calculated.

Excursion $=\left[\frac{\text { Failed test value }}{\text { Guideline value }}\right]-1$

Second, the normalized sum of excursions (nse) is calculated as follows:

nse $=\left[\frac{\sum \text { Excursion }}{\text { Total number of tests }}\right]-1$

F3 is then calculated using a formula that scales the nse to range between 1 and 100:

$F_{3}=\left[\frac{\mathrm{nse}}{0.01 \mathrm{nse}+0.01}\right]$

The index value is computed using the following formulation:

CCMEWQI $=100-\left[\frac{\sqrt{F_{1}^{2}+F_{2}^{2}+F_{3}^{2}}}{1.732}\right]$

The factor of 1.732 has been introduced to scale the index from 0 to 100 . The above formulation produces a value of CCME WQI between 0 and 100 and gives a numerical value to the state of water quality. Note a zero (0) value indicates very poor water quality, whereas a value close to 100 signifies excellent water quality. The assignment of CCME WQI values to different categories is somewhat subjective process and also demands expert judgment and public's expectations of water quality. The water quality is ranked in the following five categories:

1. Excellent (CCME WQI value 95-100)—water quality is protected with a virtual absence of threat or impairment; conditions are very close to natural or pristine levels.
2. Good (CCME WQI value $80-94)$-water quality is protected with only a minor degree of threat or impairment; conditions rarely depart from natural or desirable levels.

3. Fair (CCME WQI value 65-79) - water quality is usually protected, but occasionally threatened or impaired; conditions sometimes depart from natural or desirable levels.

4. Marginal (CCME WQI value 45-64) — water quality is frequently threatened or impaired; conditions often depart from natural or desirable levels.

5. Poor (CCME WQI value $0-44$ ) - water quality is almost always threatened or impaired; conditions usually depart from natural or desirable levels (Canadian Council of Ministers of the Environment (CCME) 2001).

The WQI software has been prepared in Visual Basic by CCME, which can be implemented in MS Excel for computational purpose. Instructions for the implementation are well described in the Calculator Version 1.0 (Canadian Council of Ministers of the Environment (CCME) 2001). The output is available in the form of a table displaying the values of $F_{1}, F_{2}, F_{3}$, WQI, number of samples, number of variables tested, total number of variables, total tests, failed tests, passed tests and tests below detection level. A frequency histogram of $F_{1}, F_{2}$, and $F_{3}$ is also given (Lumb et al. 2006).

\section{Statistical analysis}

First, the index trend and the individual quality parameters were verified along the five monitoring stations (spatial analysis). These analyses verified the water quality of the Uppanar River receiving the industrial effluents. The index values for the upstream (uncontaminated) and downstream 
(contaminated) sites were also as compared to verify the influence of the industrial zone on the water quality, through the use of the Mann-Whitney non-parametric test ( $U$ test) that is used to compare central tendencies of two groups. The lower values for $U$ showed that the groups are different, and the results were consistent with the earlier findings (Arango 2001; Callegari-Jacques 2003). Therefore, the distinctions between the following sites were tested: upstream, where water is free from anthropogenic activities, such as industries, domestic sewage and agricultural contaminations, and downstream, where the effluent disposal of all industries and the municipal sewage are discharged. The groups were considered significantly different when the error probability present was less than $5 \%$, that is, $p<0.05$.

Thereafter the quality trend by year and by seasonal period was analyzed (temporal analysis). With these analyses, it was possible to verify the influence of seasonality on the water quality of the Uppanar River, over 19 months of data collection and analysis. The relation between the indices and the average rainfall, because of its proximity to the study area was observed through the use of the Pearson's correlation test. The correlation was considered significant for a probability of less than a $5 \%$ error $(p<0.05)$. An analysis comparing groups using the MannWhitney test ( $U$ test) was also accomplished, splitting data between the humid season (July-September) and the dry season (March-June).

\section{Results and discussion}

Box-plot graphs were utilized to facilitate visualization of the results, so that the mean and the data distribution could be identified; Figs. 2(a-d), 3(a-d), $4(\mathrm{a}, \mathrm{b})$. The central trend measurement chosen to analyze DO, COD, and BOD Fig. $5(\mathrm{a}-\mathrm{c})$ was the median, as it is not influenced by extreme series values and due to their higher variations in their concentrations among the samples. It can be inferred from Fig. 2 (a) that $\mathrm{pH}$ exhibit a significant difference among the sampling sites, where $\mathrm{pH}$ at outfall and downstream fell under the permissible limit (6.5-7.5) while at the other sampling sites exceeded the guidelines. The introduction of organic matter in a water body results in the increased consumption of dissolved oxygen by the decomposing micro-organisms (Von Sperling 1996). This statement can be verified in the waters of the Uppanar River, where the lowest DO values are found at downstream. Nevertheless, the DO values are extremely low along the entire length of the stream. This fact shows that the stream is losing its auto water quality recovery capacity. The large quantity of organic matter present in the effluents discharged starting from outlet is verified through the high values of $\mathrm{BOD}_{5}$ found in the outfall and downstream. The mean values of all the other parameters are within the permissible range as recommended by Indian standards (Figs. 2, 3, and 4). The colour of the water samples were observed visually and are classified as clear water at upstream (uncontaminated) and slightly unnatural colour with foam at treated, outlet and outfall, while dark colour with strong mal odour water at treated and downstream (contaminated). A paired two-sample $t$ test considering a significance level of 0.05 has been conducted to infer statistical difference of parameters across the seasons and years. It is observed that DO and $\mathrm{BOD}_{5}$ showed significant difference during rainy and summer season in 2010 (Table 1). Total hardness, magnesium and calcium showed maximum value in NE monsoon 2010. TDS exhibit significant difference in winter and summer seasons of 2010. EC and TDS showed maximum value in SW monsoon 2010 and it was several folds higher than the winter 2010. EC, TDS, DO, sodium, and chloride showed statistical difference in summer 2010 and rainy seasons of 2010. The average values of $\mathrm{EC}$, TSS, $\mathrm{BOD}_{5}, \mathrm{COD}$, calcium, magnesium, hardness, sodium, and chloride showed significant increase in winter 2011 compared to that of winter 2010. Similarly EC, TDS, TSS, BOD 5 , COD, sodium, and chloride exhibit a higher concentration in summer 2011 compared to that of 2010. Some of the average parameter values in the rainy season showed high value due to weathering and heavy rainfall in the study area. However, most of the parameters exhibited significant increase in the year 2011 as compared to that of 2010 in winter and summer seasons that indicates the water quality parameters essentially changed across seasons and increased across the years because of industrial activities. Pearson's correlation coefficient matrix was prepared within the studied parameters in six seasons of 2 years and shown in Table 2. It is inferred from Table 2 that strong negative correlation coefficient exhibit between the parameters as follows: pH-EC (-0.802), pH-TDS (-0.844), temperature-DO $(-0.754)$, temperature-BOD (-0.754), TSS-COD (-0.955), COD-calcium (0.875), COD-magnesium (0.718), and COD-hardness (0.817). The strong positive correlation coefficient exhibit as follows: $\mathrm{pH}$-sodium (0.906), pH-chloride (0.714), EC-TDS (0.989), TSS-calcium (0.875), TSS-magnesium (0.718), TSS-hardness (0.817), calcium-magnesium (0.957), calcium-hardness (0.993), magnesium-hardness (0.985), sodium-chloride (0.935). The changes in the land use, agricultural runoffs and partially treated industrial effluents from the industrial zone in the study area could be attributed to the correlation of parameters and the present result being in consistent with earlier studies (Sahu et al. 2011). 

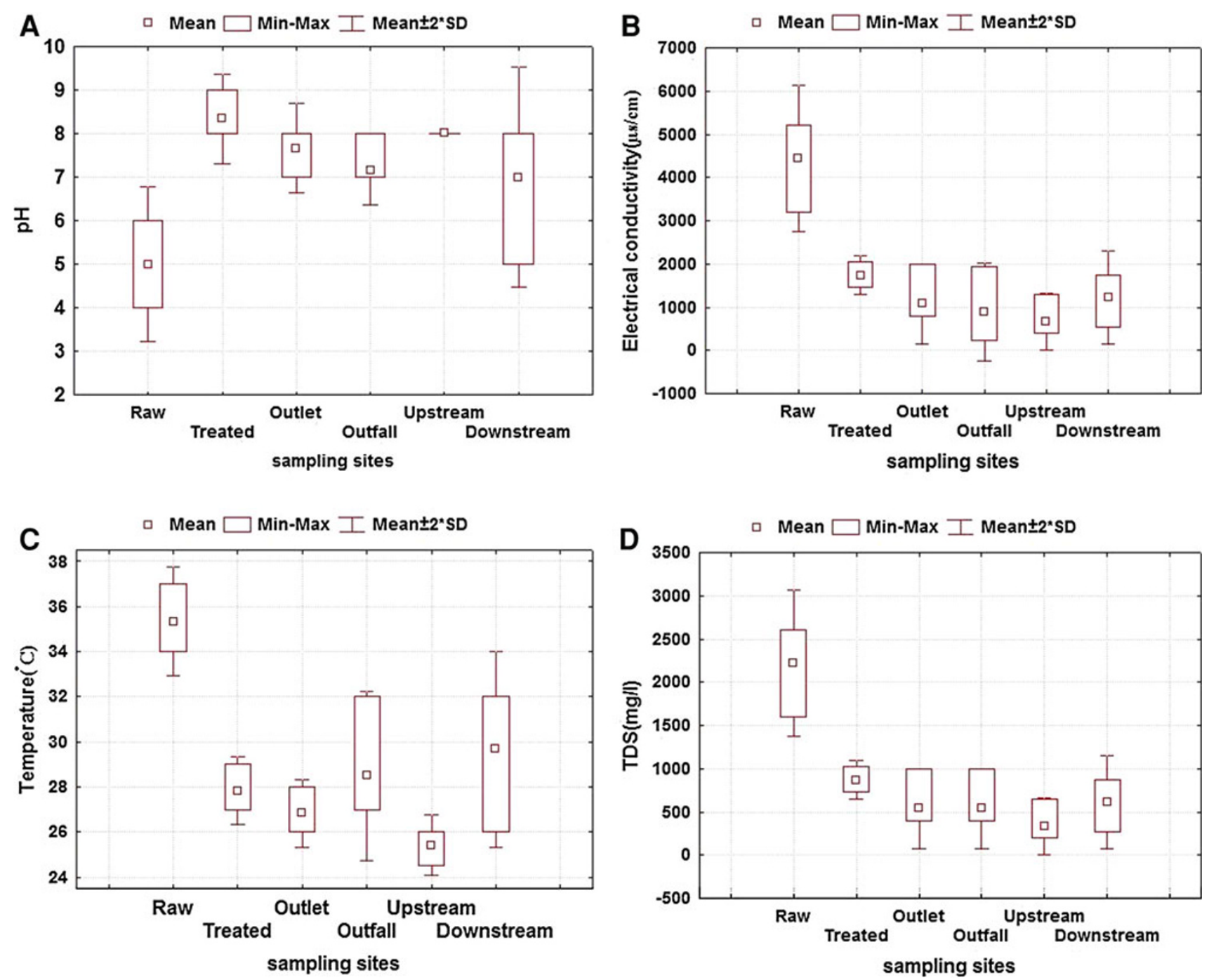

Fig. 2 Variations of pH (a), EC (b), Temperature (c), and TDS (d) over the sampling sites

Application of $\mathrm{WQI}_{\mathrm{BA}}$

The parameters used for the calculation of $\mathrm{WQI}_{\mathrm{BA}}$ were $\mathrm{pH}, \mathrm{BOD}_{5}, \mathrm{DO}$, temperature, hardness, TDS, sodium, chloride, EC, magnesium, and calcium. $\mathrm{WQI}_{\mathrm{BA}}$ indices were applied to the water samples of treated effluent, outlet, outfall, upstream and downstream to quantify the impact of treated industrial effluents on the quality of the other sampling sites. The results of index application are presented quantitatively and qualitatively corresponding to a value or grade between 0 and 100 (Table 3).

\section{Application of CCME WQI}

The critical parameters chosen to evaluate the CCME WQI were $\mathrm{pH}$, EC, TDS, calcium, magnesium, hardness, sodium, and chloride. The WQI was measured annually, as well as seasonally for a period of 2 years for all the four river samples. The WQI was determined by combining variables of interest for a particular use or application (Table 4). The index was calculated using drinking water quality prescribed by Indian standards (BIS 1991) for drinking water specification.

Statistical interpretation

By applying the ( $\left(\mathrm{WQI}_{\mathrm{BA}}\right)$ it was verified that, along the river, the worst water quality was found at downstream. This site presented the lowest median (15.33), indicating a critical water quality location of the Uppanar River. The qualitative result of $\mathrm{WQI}_{\mathrm{BA}}$ classified the treated water of pharmaceutical industry as 'bad' and outlet and outfall water as 'regular'. This highlights the delicate situation of the water quality of these sites, as it is necessary to reach a median value of 61.00 to be considered 'acceptable' (Table 3). The greater $\mathrm{WQI}_{\mathrm{BA}}$ values that indicate a better 

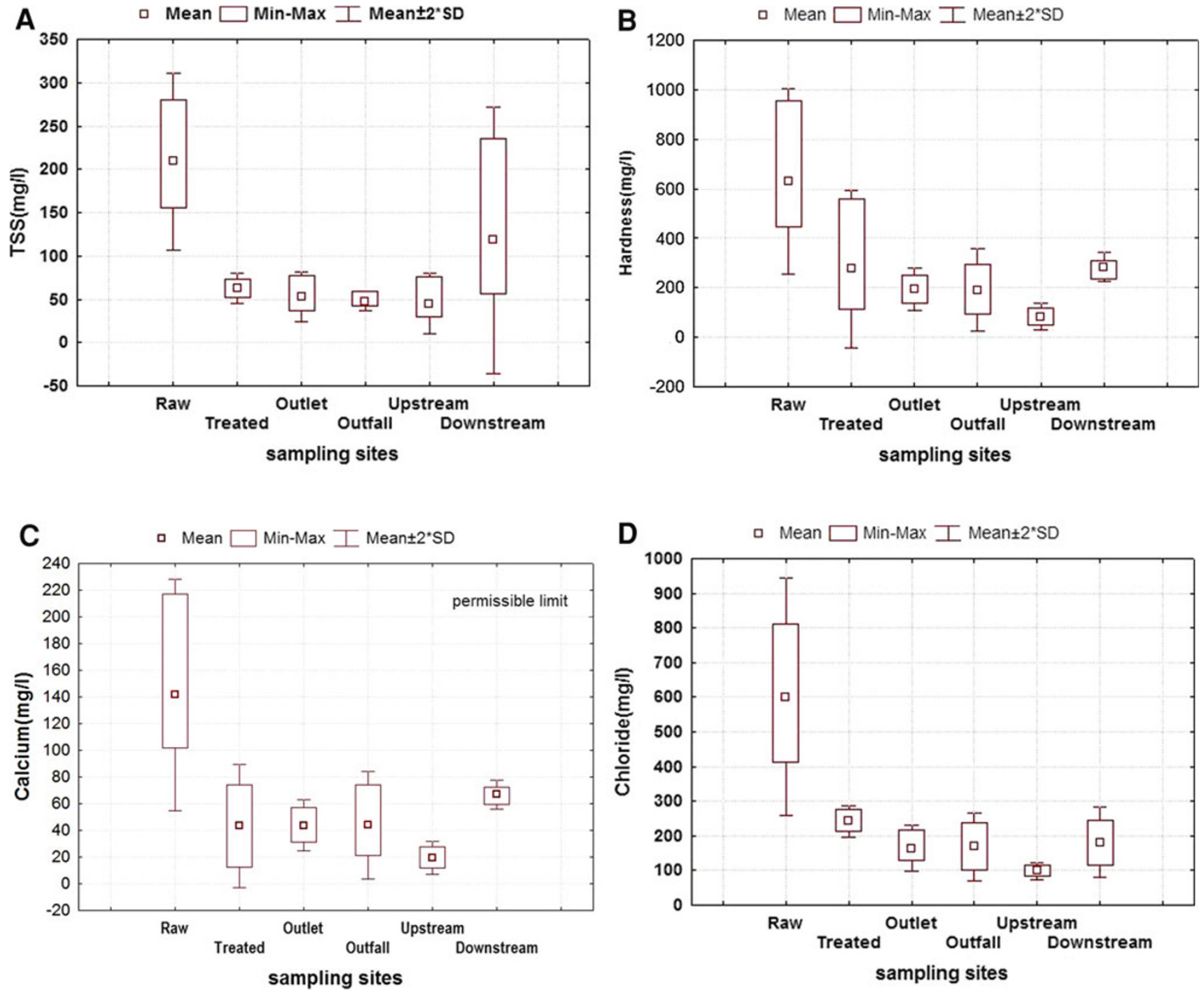

Fig. 3 Variations of TSS (a), hardness (b), calcium (c), and chloride (d) over the sampling sites
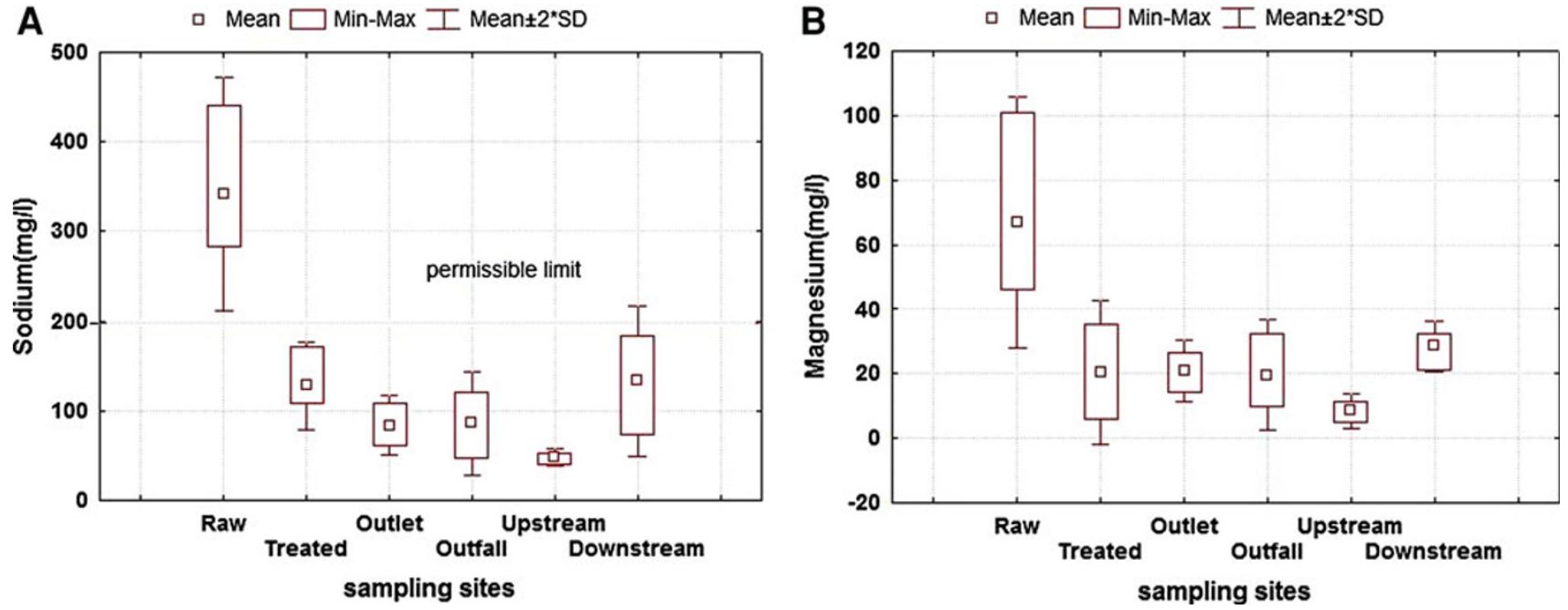

Fig. 4 Variations of sodium (a) and magnesium (b) over the sampling sites 

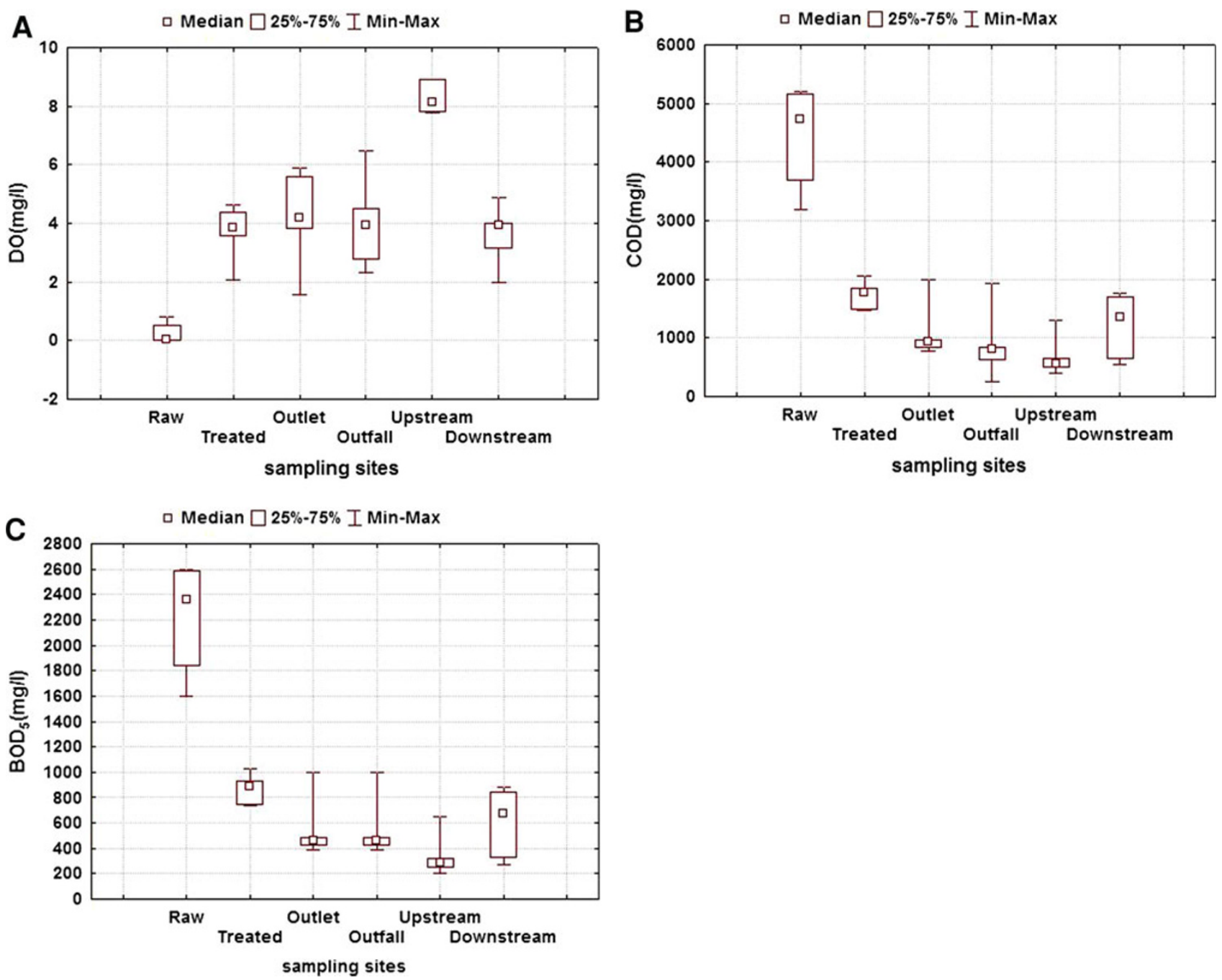

Fig. 5 Variations of DO (a), COD (b), and BOD (c) over the sampling sites

water quality were found at upstream (78.13 median). This is evident when observing Fig. 6a, where it is presented that more than $75 \%$ of the analyzed data were below this value; this means that less than $25 \%$ of data had an acceptable qualification at all stations. The Stations outlet, outfall and downstream presented medians very close to 'bad' classification, next to 'very bad' values. The results of $\mathrm{WQI}_{\mathrm{BA}}$ indicated that the water colour parameter has a considerable weight in the final results, as the constant $K$ is directly related to this parameter. All results found were below the 61.00 value, varying between 'regular', 'bad' and 'very bad'. The water color results from the existence of dissolved substances, originated mainly from organic matter decomposition processes that occur in the aquatic environment, as well as being associated with the presence of some metallic ions-iron and manganese, (Esteves 1988). Because the Uppanar River receives a large quantity of industrial effluents $(\sim 234.01 / \mathrm{s})$ and there is a small base flow $(\sim 154.2 \mathrm{l} / \mathrm{s}$ in the dry season, upstream of the industrial discharges), the quality of these effluents has a great influence on the water colour. At station downstream, the water presented a non-natural brown colouration, completely distinct from the colour observed approximately $2.0 \mathrm{~km}$ at station of upstream. This colouration is probably, due to the direct effect of the pharmaceuticals and fertilizer industries effluent disposal. Seasonal water quality results presented in Table 5 depicted the water quality at outlet falls in the marginal category. The outfall water quality falls in the poor and marginal category, while in upstream it was marginal, good and fair. The downstream water quality falls in the poor category during all the seasons except the south west monsoon. The results of present study were inconsistent with the findings of Paliwal et al. (2007) and Sharma and Singh (2009).

Through the Mann-Whitney test a significant decrease in water quality between Stations upstream and downstream was verified $[U=2509 ; p=0.0184]$. In this way, it was proved that the industrial discharges negatively 
Table 2 Correlation between water quality parameters

\begin{tabular}{|c|c|c|c|c|c|c|c|c|c|c|c|c|c|}
\hline & $\mathrm{pH}$ & Temperature & $\mathrm{EC}$ & TDS & TSS & DO & BOD & COD & Calcium & Magnesium & Hardness & Sodium & Chloride \\
\hline $\mathrm{pH}$ & 1 & & & & & & & & & & & & \\
\hline Temperature & 0.138 & 1.000 & & & & & & & & & & & \\
\hline $\mathrm{EC}$ & -0.802 & 0.048 & 1.000 & & & & & & & & & & \\
\hline TDS & -0.844 & 0.110 & 0.989 & 1.000 & & & & & & & & & \\
\hline TSS & -0.231 & 0.073 & -0.222 & -0.089 & 1.000 & & & & & & & & \\
\hline DO & -0.295 & -0.745 & 0.348 & 0.237 & -0.611 & 1.000 & & & & & & & \\
\hline BOD & 0.152 & -0.754 & -0.176 & -0.205 & 0.163 & 0.262 & 1.000 & & & & & & \\
\hline COD & 0.165 & 0.054 & 0.387 & 0.266 & -0.955 & 0.490 & -0.138 & 1.000 & & & & & \\
\hline Calcium & 0.046 & -0.296 & -0.527 & -0.435 & 0.875 & -0.380 & 0.484 & -0.922 & 1.000 & & & & \\
\hline Magnesium & 0.210 & -0.455 & -0.598 & -0.539 & 0.718 & -0.249 & 0.685 & -0.773 & 0.957 & 1.000 & & & \\
\hline Hardness & 0.113 & -0.369 & -0.561 & -0.483 & 0.817 & -0.326 & 0.574 & -0.869 & 0.993 & 0.985 & 1.000 & & \\
\hline Sodium & 0.906 & -0.146 & -0.583 & -0.671 & -0.473 & 0.052 & 0.394 & 0.427 & -0.121 & 0.128 & -0.018 & 1.000 & \\
\hline Chloride & 0.714 & -0.316 & -0.331 & -0.429 & -0.497 & 0.211 & 0.601 & 0.511 & -0.155 & 0.125 & -0.040 & 0.935 & 1 \\
\hline
\end{tabular}

Table 3 Percentage values attributed to water quality parameters for calculation of the WQI proposed by Bascarón (WQI $\left.\mathrm{WA}_{\mathrm{BA}}\right)$

\begin{tabular}{|c|c|c|c|c|c|c|c|c|c|c|c|}
\hline Parameter $\mathrm{pH}$ & $\begin{array}{l}\mathrm{BOD}_{5} \\
(\mathrm{mg} / \mathrm{l})\end{array}$ & $\begin{array}{l}\mathrm{DO} \\
(\mathrm{mg} / \mathrm{l})\end{array}$ & $\begin{array}{l}\text { Temperature } \\
\left({ }^{\circ} \mathrm{C}\right)\end{array}$ & $\begin{array}{l}\text { Hardness } \\
(\mathrm{mg} / \mathrm{l})\end{array}$ & $\begin{array}{l}\text { TDS } \\
(\mathrm{mg} / \mathrm{l})\end{array}$ & $\begin{array}{l}\text { Sodium } \\
(\mathrm{mg} / \mathrm{l})\end{array}$ & $\begin{array}{l}\text { Chloride } \\
(\mathrm{mg} / \mathrm{l})\end{array}$ & $\begin{array}{l}\mathrm{EC}(\mu \mathrm{s} / \\
\mathrm{cm})\end{array}$ & $\begin{array}{l}\text { Magnesium } \\
(\mathrm{mg} / \mathrm{l})\end{array}$ & $\begin{array}{l}\text { Calcium } \\
(\mathrm{mg} / \mathrm{l})\end{array}$ & $\begin{array}{l}C \mathrm{i} \\
(\%)\end{array}$ \\
\hline \multicolumn{12}{|l|}{ Weight- $P_{i}$} \\
\hline 1 & 3 & 4 & 1 & 1 & 2 & 1 & 1 & 4 & 1 & 1 & \\
\hline \multicolumn{12}{|c|}{ Analytical value of the parameter } \\
\hline 1 & $>15$ & 0 & $>50 />-8$ & $>1.500$ & $>20.000$ & $>500$ & $>1.500$ & $>16.000$ & $>500$ & $>1.00$ & 0 \\
\hline 2 & 12 & 1 & $45 /-6$ & 1.000 & 10.000 & 300 & 1.000 & 12.000 & 300 & 600 & 10 \\
\hline 3 & 10 & 2 & $40 /-4$ & 800 & 5.000 & 250 & 700 & 8.000 & 250 & 500 & 20 \\
\hline 4 & 8 & 3 & $36 /-2$ & 600 & 3.000 & 200 & 500 & 5.000 & 200 & 400 & 30 \\
\hline 5 & 6 & 3.5 & $32 / 0$ & 500 & 2.000 & 150 & 300 & 3.000 & 150 & 300 & 40 \\
\hline 6 & 5 & 4 & $30 / 5$ & 400 & 1.500 & 100 & 200 & 2.500 & 100 & 200 & 50 \\
\hline 6.5 & 4 & 5 & $28 / 10$ & 300 & 1.000 & 75 & 150 & 2.000 & 75 & 150 & 60 \\
\hline 9 & 3 & 6 & $26 / 12$ & 200 & 750 & 50 & 100 & 1.500 & 50 & 100 & 70 \\
\hline 8.5 & 2 & 6.5 & $24 / 14$ & 100 & 500 & 25 & 50 & 1.250 & 25 & 50 & 80 \\
\hline 8 & 1 & 7 & $22 / 15$ & 50 & 250 & 15 & 25 & 1.000 & 15 & 25 & 90 \\
\hline 7 & $<0.5$ & 7.5 & $21 / 16$ & $<25$ & $<100$ & $<10$ & 0 & $<750$ & $<10$ & $<10$ & 100 \\
\hline
\end{tabular}

Table 4 Correspondence of the qualitative results according to the numerical result of water quality index calculation $\left(\mathrm{WQI}_{\mathrm{BA}}\right)$

\begin{tabular}{ll}
\hline Quantitative index result & Qualitative corresponding result \\
\hline $91 \leq$ index $\leq 100$ & Good \\
$61 \leq$ index $<91$ & Acceptable \\
$31 \leq$ index $<61$ & Regular \\
$16 \leq$ index $<31$ & Bad \\
$0 \leq$ index $<16$ & Very bad \\
\hline
\end{tabular}

influence the Uppanar River water quality. The seasonal variation of the Bascarón Adapted Water Quality Index $\left(\mathrm{WQI}_{\mathrm{BA}}\right)$ values along the river is presented in Fig. $6 \mathrm{~b}$. When the seasonal variation was analyzed over the 2 years, the $\mathrm{WQI}_{\mathrm{BA}}$ values portray a slightly better water quality during the winter (December-February) and rainy seasons (July-November). Even so, the means of all months were considered as being of 'regular' quality (Fig. 6b). With these results, it was observed that seasonality does not significantly influence the water quality of the Uppanar River. The quality is mainly influenced by industrial effluents; regularly those discharged downstream, originating from pharmaceutical, fertilizers, chemical industries, and paint industries. The index analysis allows the evaluation of water quality changes due to the combined effect of several parameters. However, the indices are only partially indicative of quality and must not be the only way of evaluation (Conesa Fdez-Vitora 1995). 
A

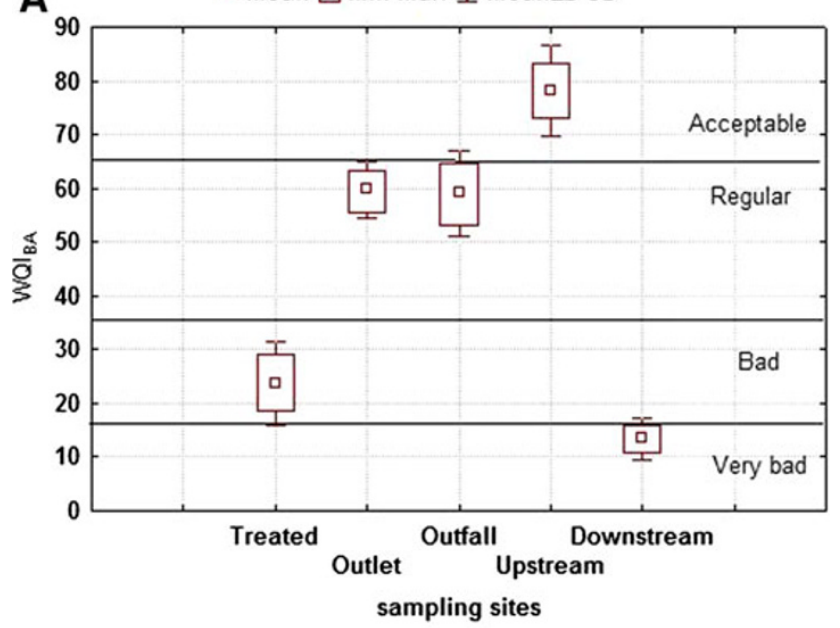

B

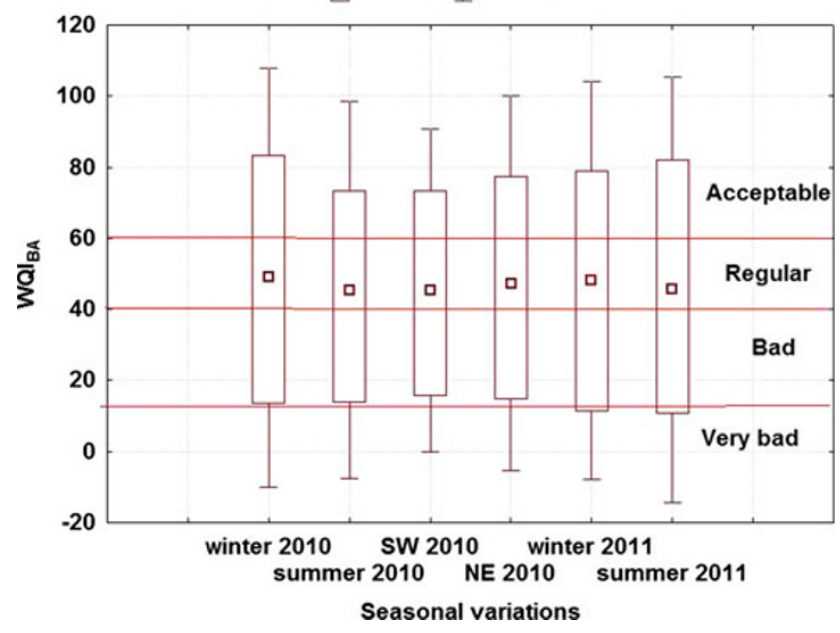

Fig. 6 Variations of water quality Index values over the sampling sites (a) and seasons (b)

CCME WQI results showed that, the River Uppanar is highly polluted and unfit for domestic purpose. Figure $7 \mathrm{a}$ represented the percentage of parameters that exceeded the guidelines. The percentage of individual tests within each parameter that exceeded the guideline is represented in Fig. $7 \mathrm{~b}$. The extent to which the failed test exceeds the guideline is presented in Fig. 7c. CCME WQI results (Fig. 8) indicated the frequency of occurrence of water quality index. It was observed that for locations downstream, outlet and outfall the water quality falls in the poor range of CCME WQI. It was also noted that calcium, magnesium, and chloride are the only parameter meeting the water quality standards throughout the stretch of the river. The presence of higher concentration of COD and $\mathrm{BOD}_{5}$ is also an important parameter that negatively impacts the river water quality. Because the river traverses through the industrial zone, it becomes polluted via point and non-point sources. During its course, the river receives both partially treated and untreated wastewater via wastewater drains. A huge amount of organic waste when added into the river, it augments the microbial activity of the aquatic system resulting in the acceleration of BOD and exhaustion of DO. According to CPCB (2006) guidelines, $\mathrm{pH}$ and DO are important to quantify the health of a river, since the water is used for fishing as it supports aquatic life. Factors affecting DO are temperature, volume and velocity of water flowing in the river, organic wastes, climate/season, type and number of organisms in the water body, altitude, dissolved or suspended solids and amount of nutrients in the water. Rivers with lower oxygen levels often smell bad because of waste products produced by organisms surviving in low oxygen environments. In addition, low DO concentrations also mobilize the trace metals (Murphy 2007). High BOD indicates that the levels of DO are falling, with potentially dangerous implications for the river's biodiversity. Elevated BOD demand can be caused due to high levels of organic pollution (caused usually by poorly treated wastewater) and high nitrate levels facilitating high plant growth. It negatively impacts on the DO of the river. Free ammonia (unionized ammonia, NH3) depletes DO in water via oxidation. Downstream of the river also receives a major load discharged from other industries and municipal sewage carrying wastewater in addition to wastewater via drains from Cuddalore city throughout the year. The river flows like an open sewer and there is hardly any aquatic life in this stretch. The main reasons for the poor quality river water are the addition of

Table 5 Seasonal CCME WQI

\begin{tabular}{|c|c|c|c|c|c|c|c|c|}
\hline \multirow{2}{*}{$\begin{array}{l}\text { Sampling sites } \\
\text { Seasons }\end{array}$} & \multicolumn{2}{|l|}{ Outlet } & \multicolumn{2}{|l|}{ Outfall } & \multicolumn{2}{|l|}{ Upstream } & \multicolumn{2}{|l|}{ Downstream } \\
\hline & CCME WQI & Category & CCME WQI & Category & CCME WQI & Category & CCME WQI & Category \\
\hline Winter 2010 & 47.9 & Marginal & 43.7 & Poor & 48.5 & Marginal & 37.1 & Poor \\
\hline Summer 2010 & 47.3 & Marginal & 45.6 & Marginal & 79.6 & Good & 35.6 & Poor \\
\hline South west 2010 & 56.1 & Marginal & 57.1 & Marginal & 45.9 & Marginal & 58.9 & Marginal \\
\hline North east 2010 & 48.2 & Marginal & 38.4 & Poor & 47.3 & Marginal & 41.8 & Poor \\
\hline Summer 2011 & 45.3 & Marginal & 58.9 & Marginal & 68.7 & Fair & 41.4 & Poor \\
\hline Winter 2011 & 46.8 & Marginal & 42.4 & Poor & 68.8 & Fair & 40.3 & Poor \\
\hline
\end{tabular}




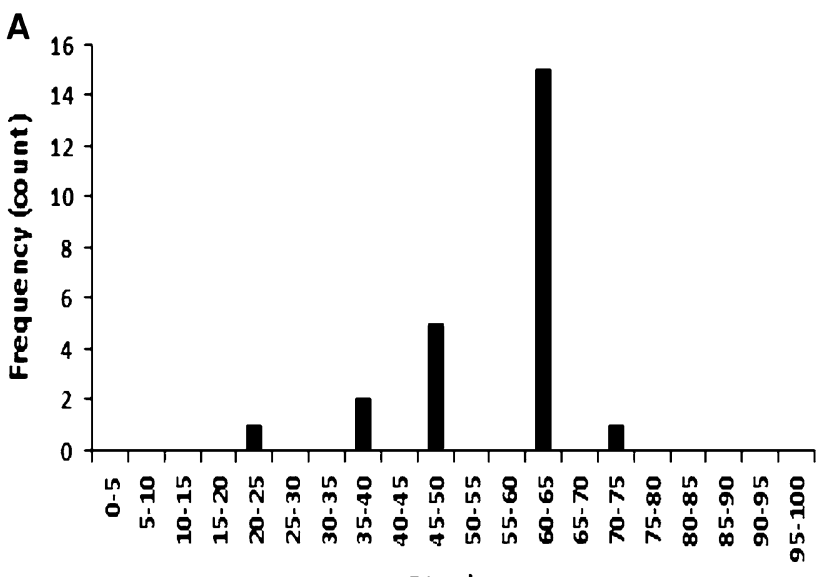

F1 value

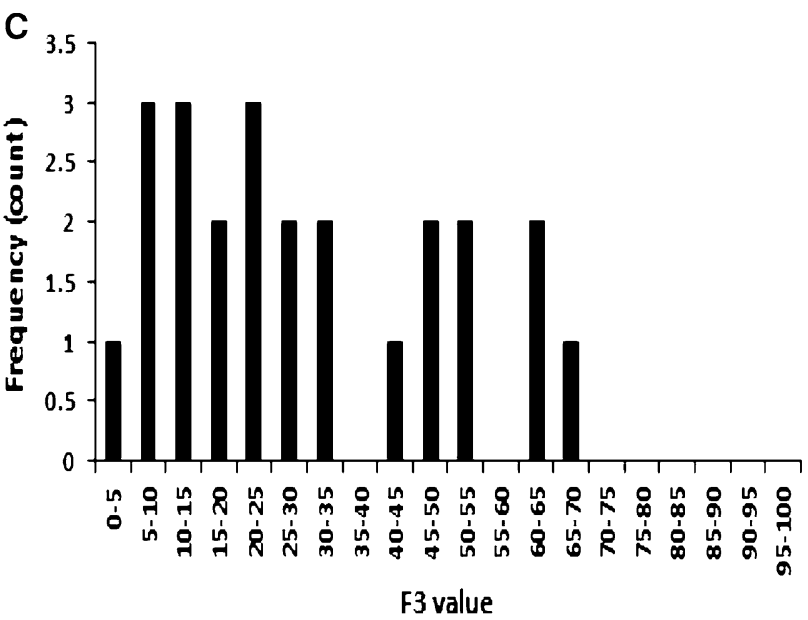

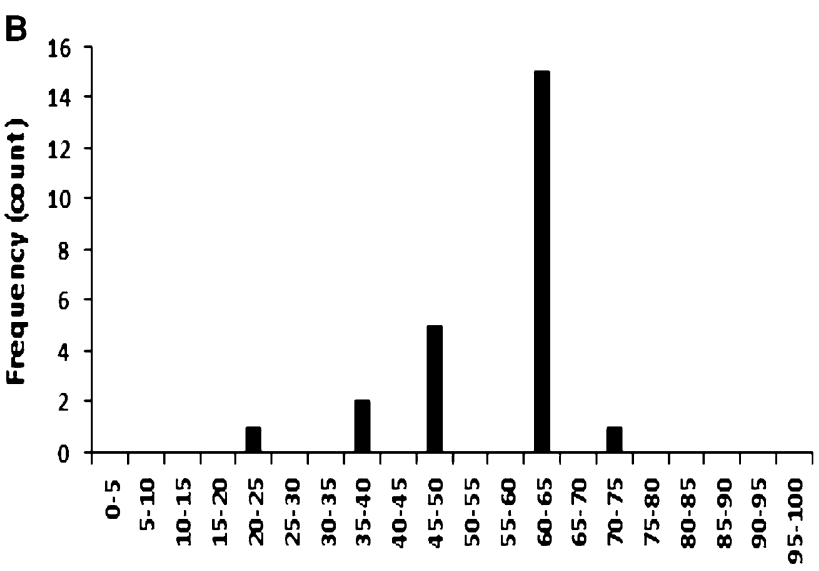

$F 2$ value

Fig. 7 Histogram showing the distribution of $F_{1}(\mathbf{a}), F_{2}(\mathbf{b})$, and $F_{3}(\mathbf{c})$ parameter

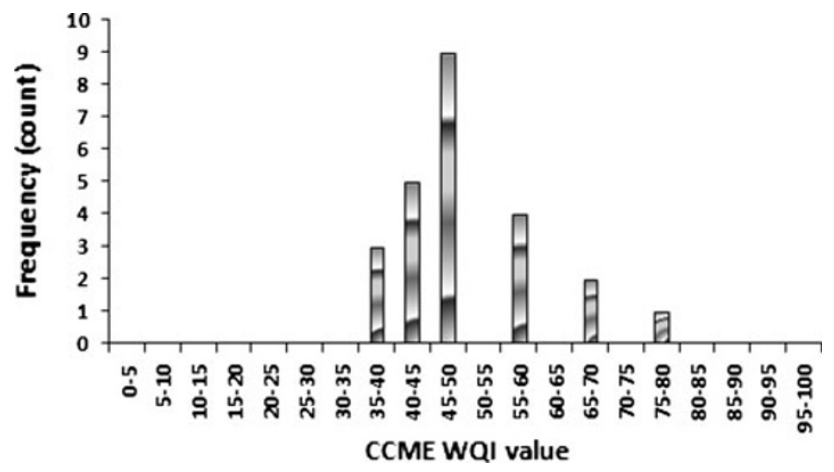

Fig. 8 Histogram showing CCME WQI

huge quantity of wastewater generated from the city and no fresh water flow into the river, as also studied by few water quality modeling studies (Paliwal et al. 2007; Sharma and Singh 2009). The water quality is highly deteriorated due to lack of minimum perennial fresh water flow in the river along the 22-km stretch between downstream and upstream.
Therefore, the water quality evaluation for the Uppanar River through the use of $\mathrm{WQI}_{\mathrm{BA}}$ and CCME WQI can be considered valid and these indices can certainly be used to evaluate other water bodies that receive industrial effluents. Owing to the flexibility of these indices, the calculation may be accomplished by inserting the parameters available. Pesce and Wunderlin (2000) obtained an index, starting from the Bascarón WQI that uses only three parameters with similar results to two other indices with 20 parameters involved in the calculation. The development and improvement of such indices is of great importance, especially for developing countries, where the costs involved in the analysis of some parameters may limit water quality evaluation. Therefore, even without the resources necessary to determine important parameters (such as heavy metals, in the case of industrial pollution), it is possible to obtain legitimate representative results. Both indices can be used combined to estimate other water courses located in industrial areas. The present results concluded that in the view of pollution control, strategies developed so far to control the water pollution have been 
found to be inappropriate in meeting the required river quality standards.

\section{Recommendations}

The industrial effluents from all the industries should be sent (through pipes) for treatment and disposal insuring 'zero' discharge into the river. The temperature of hot effluents from industries entering the river must be controlled by spray, cascading, etc., as it reduces DO levels by increasing the microbial activity (Sharma and Kansal 2009). The entire Cuddalore town must be sewered and all the wastewater even in low-lying areas near the river should be recycled and reused for irrigation, horticulture and industrial purposes. It can also be supplied for cooling the towers in power stations. The agricultural practices at Cuddalore must be improved to minimize the effects of chemical fertilizers, insecticides, pesticides, etc. There is an urgent need for developing public toilets and crematoria near the riverbanks. In addition, afforestation along the riverbanks would help controlling siltation, erosion, agricultural runoffs containing pesticides and fertilizers, etc.

\section{Conclusions}

The applied water quality indices were considered satisfactory to evaluate watercourses receiving industrial effluents. The flexibility of these indices relative to the parameters inserted in the calculations facilitates water quality evaluation in developing countries, where high cost and lack of necessary infrastructure for analyses of other parameters are current deterrents to appropriate site-specific water quality evaluation. The effluents produced by the industrial zone of SIPCOT have a significant negative effect on the water quality of the river. Both indices used, $\mathrm{WQI}_{\mathrm{BA}}$ and CCME WQI, showed that monitoring station downstream presents the worst water quality results, due to the discharge of untreated effluents. The indices also allowed verification of the poor water quality of the stream along its entire course, clearly influenced by the presence of the industrial zone of Cuddalore.

Acknowledgments Mrs. Usha Damodharan is grateful to Ecology and Environmental Science Department of Pondicherry Central University for providing her the laboratory facilities to carry out the necessary analysis, and to Pondicherry University for awarding her a university fellowship. This paper is a part of her PhD research work.

Open Access This article is distributed under the terms of the Creative Commons Attribution License which permits any use, distribution, and reproduction in any medium, provided the original author(s) and the source are credited.

\section{References}

Almeida MAB, Schwarzbold A (2003) Avaliação sazonal da qualidade das águas do arroio da Cria Montenegro, RS com aplicação de um índice de qualidade da água (IQA). RBRH 8:81-97

Arango HG (2001) Bioestatística teórica e computacional. Guanabara Koogan, Rio de Janeiro

Bascarón GM (1979) Estabelecimiento de una metodologia para conocer la calidad del agua. Boletin Informativo del Medio Ambi-ente 1(1):30-49

Bhargava DS (1983) Use of water quality index for river classification and zoning of Ganga River. Environ Pollut Ser B (Engl) 6(1):51-67

Bhargava DS (1994) River BOD prediction under non-point discharge conditions. Indian J Eng Mater Sci 1(1):35-40

BIS (1991) Specification for drinking water. Second revision of IS: 10500

Brown RM, Mc Clelland NI, Deininger RA, Ronald GT (1970) A water quality index do we dare? Water Sew Works 117(10):339-343

Cahill JD, Furlong ET, Burkhardt MR, Kolpin D, Anderson LG (2004) Determination of pharmaceutical compounds in surfaceand ground-water samples by solid phase extraction and highperformance liquid chromatography-electrospray ionization mass spectrometry. J Chromatogr A 1041(1-2):171-180

Callegari-jacques SM (2003) Bioestatística: Princípios e Apli-cações. Artmed, Porto Alegre

Canadian Council of Ministers of the Environment (CCME) (2001) Canadian water quality guidelines for the protection of aquatic life: CCME Water Quality Index 1.0, Technical Report. In: Canadian environmental quality guidelines, 1999. Canadian Council of Ministers of the Environment, Winnipeg. http://www.ccme.ca/assets/pdf/wqi_techrprtfctsht_e.pdf

Conesa fdez-vitora V (1995) Methodological Guide for Environmental Impact Evaluation (Guía Metodológica para la Evaluación del Impacto Ambiental). Mundi-Prensa, Madrid

CPCB (2006-07) Water quality status of River Yamuna (1999-2005), assessment and development study of river basin series (ADSORBS). ADSORBS/41. Central Pollution Control Board, Delhi, India

Debska J, Kot-Wasik A, Namiesnik J (2004) Fate and analysis of pharmaceutical residues in the aquatic environment. Crit Rev Anal Chem 34(1):51-67

Dinius SH (1972) Social accounting system for evaluating water resource. Water Resour Res 8(5):1159-1177

EPI (2010) Yale Center for Environmental Law and Policy, Yale University, Center for International Earth Science Information Network (CIESIN) Columbia University, in collaboration with World Economic Forum, Geneva, Switzerland and Joint Research Centre of the European Commission, Ispra, Italy. Can be viewed at http://sedac.ciesin.columbia.edu/es/epi/papers/ 2008EPI_mainreport_july10.pdf

Esteves FA (1988) Fundamentos de Limnologia. FINEP, Rio de Janeiro

Gomez MJ, Petrovic M, Fernandez-Alba AR, Barcelo D (2006) Determination of pharmaceuticals of various therapeutic classes by solid-phase extraction and liquid chromatography and mass spectrometry analysis in hospital effluent wastewaters. J Chromatogr A 1114(2):224-233

Heberer T (2002) Occurrence, fate, and removal of pharmaceutical residues in the aquatic environment: a review of recent research data. Toxicol Lett 131(1-2):5-17

Hernando MD, Petrovic M, Fernandez-Alba AR, Barcelo D (2004) Analysis by liquid chromatography-electro spray ionization tandem mass spectrometry and acute toxicity evaluation for 
beta-blockers and lipid-regulating agents in wastewater samples. J Chromatogr A 1046(1-2):133-140

Horton RK (1965) An index number system for rating water quality. J Water Pollut Control Fed 37(3):300-306

Jones AH, Voulvoulis N, Lester JN (2004) Potential ecological and human health risks associated with the presence of pharmaceutically active compounds in the aquatic environment. Crit Rev Toxicol 34(4):335-350

Jorgensen SE, Halling-Sorensen B (2000) Drugs in the environment. Chemosphere 40(7):691-699

Landwehr JM (1974) Water quality indices construction and analysis. Dissertation University of Michigan, Ann Arbor

Landwehr JM (1979) A statistical view of class of water quality indices. Water Resour Res 15(2):460-468

Landwehr JM, Deininger RA (1976) A comparison of several water quality indices. J Water Pollut Control Fed 48(5):954-958

Lohani BN, Todino G (1984) Water quality index for Chao Phrayariver. J Environ Eng 110(6):1163-1176

Lumb A, Halliwell D, Sharma T (2006) Application of CCME water quality index to monitor water quality: a case of the Mackenzie River Basin Canada. Environ Monit Assess 113:411-429

Murphy S (2007) General information on dissolved oxygen. City of Boulder/USGS water quality monitoring. Retrieved Jul 10, 2007, from http://bcn.boulder.co.us/basin/data/BACT/info/DO.html

Paliwal R, Sharma P, Kansal A (2007) Water quality modelling of the river Yamuna (India) using QUAL2E-UNCAS. J Environ Manag 83(2):131-144

Pesce SF, Wunderlin DA (2000) Use of water quality indices to verify the impact of Cordoba city (Argentina) on Suquy'a River. Water Res 34(11):2915-2926

Raphael Abrahão (2007) Use of index analysis to evaluate the water quality of a stream receiving industrial effluents, Vol. 33 No. 4. Water SA. http://www.wrc.org.za
Rocchini R, Swain LG (1995) The British Columbia water quality index. Water Quality Branch, EP Department, B.C., Ministry of Environment, Land and Park, Victoria

Sahu M, Mahapatra SS, Sahu HB, Patel RK (2011) Prediction of water quality index using neuro fuzzy inference system. Water Qual Expo Health 3:175-191. doi:10.1007/s12403-011-0054-7

Sharma D, Kansal A (2009) Water quality analysis of River Yamuna using water quality index in the national capital territory, India (2000-2009). Appl Water Sci (2011) 1:147-157. doi:10.1007/ s13201-011-0011-4

Sharma D, Singh RK (2009) DO-BOD modeling of River Yamuna for national capital territory, India using STREAM II, a 2D water quality model. Environ Monit Assess 159(1-4):231-240

SOE Report (1997) The state of the environment report. Process and criteria for indicator selection. Manitoba, Canada. Can be viewed at http://www.manitoba.ca/conservation/annual-reports/soe-reports/ soe97/append.html

Stackelberg PE, Furlong ET, Meyer MT, Zaugg SD, Henderson AK, Reissman DB (2004) Persistence of pharmaceutical compounds and other organic wastewater contaminants in a conventional drinking-water treatment plant. Sci Total Environ 329(1-3): 99-113

Standard Methods (1995) Standard methods for the examination of water and wastewater. American Public Health Association, Washington

Von sperling M (1996) Princípios do Tratamento Biológico de Águas Residuárias: Introdução à Qualidade das Águas e ao Trata-mento de Esgotos. DESA/UFMG, Belo Horizonte

Zandbergen PA, Hall KJ (1998) Analysis of the British Columbia Water Quality Index for watershed managers: a case study of two small watersheds. Water Qual Res J Can 33:519-549 